\title{
RECENT CHANGES IN FRENCH POLICY ON VENEREAL DISEASES AND PROSTITUTION* $\dagger$
}

\author{
BY \\ CICELY WATSON
}

London

In recent years the social scientist has shown as much interest in the so-called social evils, such as venereal disease, as has the medical scientist seeking a cure. Developments in the rapid and effective treatment of syphilis and gonorrhoea have been paralleled, though without the same success, by legislation to deal with the social problems they present. Attempts to combat the diseases at source have led to consideration of the control of prostitution and methods of epidemiological investigation of infectious contacts. Unfortunately, there has been little agreement between those who approach the problem of venereal disease as moral reformers and those whose aim is simply to diminish the possibility of infection and to ensure the efficient, speedy treatment of all those who have contracted the disease. In addition, objective evaluation of the various policies proposed is made difficult by the lack of reliable statistics on the incidence of the disease. But in spite of this, an account of French experience in the field is of interest because of the variety of control legislation attempted.

The first important official action to deal with the problem of venereal disease in France came in 1924 with the passing of a law which assured the patient free and confidential treatment. Special clinics were set up (both individually, sponsored by various reform bodies, and attached to hospitals), but they operated mainly in the larger towns and cities. The majority of cases were (as they still are) treated by private practitioners who thenceforth received a subsidy for each patient plus a free supply of whatever drugs or medicines were prescribed. This law merely provided for a special health service. The patient was in no way coerced or required to seek treatment or to continue with it until he or she had ceased to be infectious; nor was the physician forced to disclose any information regarding the patient, the extent of the disease, or the treatment

* Received for publication December 3, 1953.

TThis is one of a series of papers on French population and social problems prepared by Dr. Watson under the auspices of the Population Investigation Committee, London School of Economics. followed. No facilities existed for diagnosis or detection of the disease among the population at large, nor for following up the contacts of the patients to discover the source of infection and other possible cases. In general, venereal diseases were considered like any other illness to be treated by the family physician.

However, some recognition was given to the social nature of the disease by attempts to control prostitution. Recognizing that prostitutes were the principal source of infection, the government followed a policy of legalized and licensed prostitution with strict medical supervision of the women concerned. In 1938 there were two kinds of " official" prostitutes in France, those employed in the maisons tolérées and those practising en carte. The maisons tolérées were licensed brothels, owned privately or by the municipality, and the prostitutes were medically examined each week. These establishments were generally operated as " respectable " businesses; the girls were strictly chaperoned outside business hours and were adequately paid. In 1938 there were some 196 of these houses in Paris, employing 1,500 girls, 819 in the provinces, and 61 in Algeria; the total number of girls employed being 4,900 (Lahille, 1939). The prostitutes en carte were much more numerous. In 1938 in the Paris area alone there were 6,000 such women. They solicited men openly, either as their sole means of income or on a part-time basis, and worked independently or on a percentage arrangement for the owner of a bar, dance-hall, or apartment block. They invariably had a special " beat" or headquarters for seeking customers and took their clients to a furnished room or flat. There was an element of stability in their activities which lent itself to fairly constant supervision. In order to retain their carte (which did not "legalize" their work-because prostitution is not illegal in Francebut ensured both them and their clients a measure of medical protection), the women were obliged to report weekly at the local Prefecture of Police or Gendarmerie for a blood test and medical examination. Periodically their rooms were inspected by the 
police to ensure that they achieved a certain standard of cleanliness and sanitation.

In addition to the above, there were the clandestines, women of the streets, who escaped all medical control and whose rooms were subject to no supervision. It is difficult to obtain accurate information as to how many such women were operating in France in 1938, because they included many " nonprofessionals", persons employed in low-paid jobs as shop assistants and domestic servants and practising prostitution intermittently when they needed money urgently or were temporarily unemployed. Frappa (cited by Lahille, 1939) gives estimates ranging from $18,000-20,000$ for Paris alone.

In spite of many and valid criticisms as to the effectiveness of this medical control,* it was held by most physicians and social workers to have had some success, since the chance of infection from a clandestine was considerably greater than from a licensed prostitute. This contention is almost incapable of statistical proof since no accurate figures exist as to the actual number of women involved, the number of clients each had per week, or the number of venereal disease cases originating from each. However, the experience of one of France's foremost venereologists, as reported to the Society of Dermatologists and Venereologists in 1937, stating that 2,148 cases had been recorded, suggests that the claim may be justified (Touraine, 1937).

Since the incidence of venereal disease continued high in spite of these control measures, the French government (by the decree of October 30, 1938) organized a national venereal disease service, setting up free municipal clinics and giving local health authorities powers for more stringent supervision of prostitutes. The measure was widely criticized as too timid, both by the pro-natalist and family associations which opposed all licensed prostitution on moral grounds as a danger to the family, and by physicians and others who advocated the adoption of real controls empowering the police to trace all the contacts of an infected prostitute and to compel them to undergo treatment. But although criticism of the existing system was widespread there was disagreement on the measures necessary to improve it, and the medical associations opposed any regulation which would require their members to commit a breach of professional secrecy by reporting

\footnotetext{
* Objections were that in practice the physicians saw only a proportion of the girls each week and that their examination was superficial ; that a woman certified as healthy one morning might contract V.D. that evening and would continue working and infecting clients for another 7 days ; that the police were alleged to accept bribes to " fix" the cards of prostitutes who were infected; and that in some cities the police even ran a " protection" racket.
}

patients to the police or by passing on information regarding the nature of their illness.

No mention of venereal disease and prostitution control was made in the Code de la famille of July, 1939 , but critics of the régime were successful in persuading the government to amplify the regulations by the law of November 29, 1939, which placed additional responsibilities on the physician carrying out treatment (Journal Officiel, December 7, 1939, pp. 13748-49). He was required to explain to his patient the serious and infectious nature of the disease, and was warned that if he had any suspicion that the patient would refuse to undergo full treatment or was exposing a third party to infection, he should (but was not obliged to) notify the local health authority. The Medical Officer of Health might compel a patient to submit to such treatment as would make him non-infectious; Article 10 empowered him to arrange supervised visits either to a clinic or to a physician of the patient's choice. A new "crime" was created, that of being contaminated with a venereal disease of an infectious nature, and under Article 4 the public authority (either the police or the Medical Officer of Health) could require a suspect to produce a medical certificate stating that he was not infectious. Rules were laid down to try to safeguard children against infection. $\dagger$ But the control was not effective. It included no sanction against the patient who refused to submit to the supervised treatment : nor could a physician be required to testify against his patient (Peytel, 1944 ; 1945).

With the outbreak of war in 1939 and the sharp rise in prostitution and in the incidence of venereal disease, many critics of stricter control measures were silenced by the seriousness of the situation. The public health regulation of March 19, 1940, set out in detail a programme to be followed by the Medical Officer of Health of each département (Journal Officiel, March 21, 1940, pp. 2103-5). Under this scheme known syphilitics would be reported by army personnel, social workers, and other public officials in contact with homes and institutions. (Doctors were still not expected to give information about their own patients.) The infected persons were required to follow advice on treatment or to produce evidence of freedom from infection. All prostitutes were to be forced, on pain of fines and imprisonment, to submit to regular medical, microbiological, and serological examination, and to

+ Imprisonment of from 15 days to 3 months and a fine of $100-3,000$ francs might be imposed on a woman nursing or caring for a child not her own while knowingly suffering from a venereal disease. The same penalties might apply to the parent or guardian of the child who, knowing the condition of the nurse, had confided it to her care or to those who placed an infected child in a nursery. 
supervised treatment if they were found to be infected. Those imprisoned for failure to comply with the regulations would be required to continue treatment after they were released. Unfortunately, there was still no means of compelling the civilian patient (the army dealt strictly with evasion of treatment) who was not a prostitute to submit to treatment against his or her will. Further, the chaotic situation in 1940 coupled with the destitution of large numbers of refugees fleeing to the south made adequate control impossible.*

The response of the Vichy government to this problem was legislation in three directions : attempts to regulate prostitution, particularly in the large brothels; efforts to obtain the co-operation of physicians for the reporting and supervised treatment of infectious cases; and measures to extend and perfect the organization of treatment to make it convenient and accessible to all. The second point was especially stressed. A circular of the Ministère de la Santé Publique, issued on January 14, 1941, outlined the duty of physicians with regard to syphilitic patients. All infectious patients had to be reported to the local Medical Officer immediately, together with details of the nature and extent of the disease. Further, the physician was required to conduct an epidemiological inquiry as to the origin of the infection and any subsequent contacts the patient might have had with third parties. This information, followed up in so far as the physician was personally able, would be entered on official forms and forwarded within 24 hours to the local health authority. $\dagger$ Normally the name of the patient would not be reported (he would be identified by a number), but where a physician had an infectious patient who refused treatment or attended irregularly he was to report him by name with address and full particulars. This report was to reach the local medical authority within 8 days of the time when his persuasive efforts proved ineffective. The Medical Officer of Health was then empowered to order compulsory treatment in hospital (Périn, 1941). +

* What made supervision especially difficult was the large number of amateur or new professional prostitutes entering the field-women whose husbands were in the forces and who supplemented their income by entertaining soldiers, or refugees uprooted from their home communities and temporarily out of work, etc.

+ Where the physician was able to investigate the contacts himself it was not necessary to forward the information to the authorities, he could simply report the case by a number adding the words "Enquête en cours".

¥When a physician found that his patient had had previous treatment for a venereal disease, he was required to obtain the name of the physician who had previously treated him and to report the relapse, but this was seldom done. If the patient refused to name his former doctor, he was to be reported by name to the local authority, so that the Medical Officer of Health of the other departement might also be notified; this was very seldom done.
But the system, complete as it was on paper, never worked in practice. First, the physicians refused to co-operate; few kept exact records or reported by number in accurate fashion, and the cases reported by name were negligible. The epidemiological investigation required of the physician was frequently beyond his capabilities and in any case required too much time. Trained social workers or the police were best suited for this kind of work. Further, the delay periods ( 24 hours and 8 days respectively) would have been sufficient to ensure the escape of a patient really determined to evade treatment, even if the physicians had cooperated wholeheartedly.

The Vichy authorities next tried to improve the status of the maisons de tolerance in order to boost their prestige and lower that of other prostitutes, the argument being that these establishments were the least dangerous. Accordingly, much to the disgust of the moral reformers, the law of December 31, 1941, granted the operators of licensed brothels similar income tax exemptions to those enjoyed by the entrepreneurs of " public spectacles of the third category "§ (Journal Officiel, January 1, 1942, p.16). The law of April 11, 1942, gave the brothel-keepers representation on the Comité d'organisation professionnel de l'industrie hôtelière.

With the law of December 31, 1942, the Vichy authorities scored their greatest success (Journal Officiel, March 3, 1943, p. 601). This law concerned all those infected with syphilis, gonorrhoea, and soft chancre, and represented a complete victory over the physicians. The responsibility for deciding whether or not to report a patient by name no longer lay with them. Treatment of venereal disease was made compulsory, whoever the patient might be, on pain of imprisonment. Notification of the case to the local authority was also compulsory, but it would be "simple" (i.e. would not include the name of the patient), unless the patient refused to start or continue treatment, or was a prostitute, or by his or her work or way of life risked transmitting the disease to a third party. In such cases the doctor had to report the person immediately by name.\| In all cases he was required to make an epidemiological inquiry.

Treatment was to be compulsory but confidential -patients at clinics being known by numbers or pseudonyms. In addition, all publicity concerning the treatment of the diseases and the medicines or drugs used therein, whether for commercial or other

\footnotetext{
$\S$ Horse and dog racing, speedway racing, athletic meetings, football matches, etc.

Exception was made if the patient was pregnant.
} 
purposes, was forbidden.* This attempt to drive patent or home remedies off the market became the more necessary as the enforcement of the law became more thorough. Severity in dealing with syphilitic prostitutes, in particular, made them reluctant to consult reputable physicians and increased their reliance on home remedies. Generally, treatment was given at a special clinic, or hospital out-patient department, or by a private physician, but hospitalization was required of all reported by name.

In 1943 two further decrees were issued to improve the service. That of February 25, 1943, authorized the appointment of one or more official consultants in venereology for each département, with the duties of centralizing venereal disease information for the district, directing propaganda, and advising physicians and clinics on treatment (Journal Officiel, March 6, 1943, p. 655). $\dagger$ A decree of July 20, 1943, detailed the information required of physicians in their reports and drafted the official forms to be used (Journal Officiel, August 5, 1943, p. 2044). Concurrently an effort was made to limit prostitution and thus to control the disease at source : the law of March 2, 1942, contained penalties, not against prostitution itself, the legal position of which was unchanged, but against pimps, those employing or living off the earnings of the prostitution of others.

Post-war regulation of venereal disease proper has continued along the lines developed before the war and under the Vichy administration. But with regard to prostitution, the policy has been reversed. The necessity for control is still admitted to be the fundamental problem, but opinion has changed regarding the best method of ensuring it.

France had passed through a period of national disunity, defeat, and shame, accompanied by much soul-searching and self-criticism on the part of the more responsible of her citizens. The Underground and Liberation movements, as is often the case with such dangerous ventures, exhibited strong ascetic not to say puritanical characteristics, and aroused ruthless condemnation of the pre-war French society which was held responsible for the débâcle. Added to this was the new political influence of organized groups of women, who were shortly to receive the vote for the first time, most of whom opposed licensed prostitution on grounds of " public

* Accounts in professional journals had to be so worded as to be unintelligible to the general public.

+ A decree of December 30, 1942 (Journal Officiel, January 24, 1943 , p. 231) had created a permanent hygiene council with at least one venereologist member. morality ". The public attitude, at least in so far as it was openly proclaimed, had changed toward the prostitutes en carte and the maisons tolérées. Such institutions were condemned as a " recognition and approval of vice". As a result, therefore, the emphasis in the battle against venereal diseases shifted to the control of diseased prostitutes.

The first manifestation of the change came on April 11, 1946, when the National Constituent Assembly passed a resolution urging the government to undertake a general attack on venereal disease, prostitution, and other evidence of public vice (Journal Officiel (Débats), April 12, 1946, p. 1710). Two days later by an overwhelming majority a law was enacted reinforcing the penalties for procuring, closing the licensed brothels, and abolishing the system of cartes (Journal Officiel, April 14, 1946, p. 3138). In effect, this freed prostitution from police and medical control. The houses were closed at different dates throughout the year, their employees being released gradually. In theory, before their release, the girls were placed in suitable jobs by social service agencies, but in practice most of them resorted to street soliciting as clandestines. In Paris some seventy establishments closed almost immediately on April 17, 1946, and a further 35 and 58 followed on September 29 and October 7 respectively (Blum, 1947). Similar action was taken in the provinces.

By the law of April 24, 1946, a new system of prostitution control was set up, without the former "licensing" and " police control" (Journal Officiel, April 25, 1946, p. 3422). A list of prostitutes was to be compiled, with a purely sanitary (i.e. medical) aim-the immediate diagnosis and treatment of any prostitute contracting disease. The new system, elaborated by several decrees during the following 2 years, would also provide a co-ordinated and centralized picture of prostitution for each region and for the country as a whole (Law of July 8, 1948, Journal Officiel, July 9, 1948, p. 6642-3 ; Decree of November 5, 1947, Journal Officiel, November 23, 1947, p. 11585).

A confidential list of all known prostitutes $\ddagger$ was to be drawn up under the direction of the head of the venereology section of the Ministère de Population et de la Famille (1948a). This, in effect, would be the combination of a series of similar lists established in the various localities by Medical

‡ The definition of a prostitute was : " . . . any woman who consents habitually to sexual intercourse with an indeterminate number of individuals generally for payment and any woman against whom there exists substantial and precise presumptions leading one to conclude that she is practising prostitution." 
Officers of Health in consultation with the police and others. The following were to be included*:

(i) any woman who had formerly worked in a maison tolérée or held a carte ;

(ii) any woman convicted of soliciting while suffering from a venereal disease in its infectious form ;

(iii) any woman found guilty of a breach of the law as a result of which it was clear that she gained her living from prostitution (Ministère de Population, 1948a).

The decision to have a woman put on the list of prostitutes would be taken by a Commission départementale $d u$ fichier, presided over by the local Medical Officer of Health. A representative of the Ministry of Health and Population, the physician in charge of the municipal or departmental venereal disease clinic, a social worker from the unit attached to the same clinic, and a representative of the area branch of the Medical Association would be included as members of the Commission.

A dossier for each woman on the list would be held in her département of residence, but copies of all documents would be forwarded to Paris for the national list. The dossier would consist of three parts :

(i) personal section, containing a photograph, fingerprints, signature, names and aliases, address, civil status, age, etc ;

(ii) medical section, with reports of all examinations, tests, and treatment ;

(iii) social section, with information concerning the woman's family, other employment (if any), age at which she began prostitution, circumstances surrounding her first prostitution, number of children, etc.

Any woman ceasing to be a prostitute might after investigation and appropriate safeguards have her name erased from the list $\dagger$ (Ministère de Population, 1948b).

This scheme was intended to eliminate the police almost completely from the control system. It was no longer to be coercive but merely of a medical and social character. It depended entirely for its operation and success on the examining physicians both in the clinics and in private practice, who compiled the medical section of the dossiers. When a woman suffering from a venereal disease presented herself at

\footnotetext{
* Minors were not to be put on the list but were to be kept under supervision for a time to ensure that they did not return to prostitution. A prostitute convicted for a second time was to be put on the list even if at the time she was not infected. (Article 2 of the Law of April 24, 1946, and Article 2 of the Decree of November 5, 1947).

$\dagger$ Requests for erasure from the list were sent to the local department of health together with the reasons why such action should be taken and proof of the statements. Inquiries were then made by a social worker, and 3 months later the dossier was "closed" and the name excluded from the list. After 5 years, providing that the woman did not practise prostitution during that time, the dossier would be destroyed.
}

the surgery, the physician would not only treat the illness and inquire into the source of infection and possible contacts, but would also determine whether she was a prostitute who ought to be included on the list. If there was the slightest suspicion that this was the case he was obliged to forward his information to the Commission départementale du fichier.

All persons on the list were required to undergo bi-weekly examinations by their private physician or at a venereal disease clinic and to notify the Commission of any change of address. If the prostitute moved from the district her dossier was forwarded to her new département. If she contracted a venereal disease she was obliged to enter hospital immediately for treatment, $\ddagger$ and was not permitted to leave until she was no longer infectious. After her release treatment must be continued until a complete cure was obtained (Journal Officiel, August 19, 1948, p. 8150). Penalties of fines and imprisonment were provided for failure to comply with these regulations, as well as for false information given either by the prostitute or the physician.

Before we consider the reaction of physicians and laymen to this new system and their opinion of its efficacy, let us compare it with the preceding scheme by examining some of the statistics of reported cases in 1939 and since. The difficulty in assessing the seriousness of venereal disease is that few countries had an effective system of reporting cases before the second world war. Statistics, therefore, are largely merely estimates. Venereal disease only became compulsorily notifiable in France in 1942 , and even to-day the national figures are open to question because many medical practitioners are strongly opposed in principle to notification. But it is evident that from 1940 onward, when mobilization and conscription were well advanced, the incidence of venereal disease rose sharply and continued high until after the Liberation. Dispensaries and clinics, which in France have never handled the bulk of the cases, reported an increase of 100 per cent. in cases of syphilis between 1941 and 1942, and a further rise of 100 per cent. between 1942 and 1943 (UNRRA, 1945). It is reasonable to suppose that private practitioners experienced a similar increase.

It would appear that the situation was most serious in the Occupied Zone, though the presence of Italian troops in the South is also blamed.

\footnotetext{
$\ddagger$ Hospital treatment, whether as an in-patient or an out-patient, was free (Article 8 of the Law of July 8, 1948). Venereal disease dispensaries run by private organizations were subsidized up to 50 per cent. of their costs (Law of August 18, 1948). The Caisses de sécurité sociale also contributed to these costs, basing the amount on the numbers of patients insured.
} 
According to Cavaillon (1948a), although there was a considerable increase in cases in the southern zone, this was only apparent after the entry of the German forces into that area in 1943. Aujaleu and Péquignot (1947) also claimed that the really serious incidence of the disease in the north was not felt until the Occupation was well established. As the shortages of various commodities became acute and amateur and semi-professional prostitution flourished, the number of cases rose sharply, particularly among the civilian population. In the autumn of 1942 , Touraine estimated that there were some 4 to 6 million men, women, and children infected with syphilis, and that the annual number of new cases was between 80,000 and 85,000 (Touraine, 1942 ; Cavaillon, 1945). On the evidence of hospital reports there can be no doubt that in France there was a sudden rise in the incidence of venereal diseases from 1941, which continued even after the Liberation and that the situation has only gradually returned to the pre-war level (Table I).

The limited evidence available indicates that the control measures instituted by the Vichy and postwar governments have so far failed to stamp out the disease. One main reason for this is that the public at large and the authorities who apply the regulations (the police and the physicians) are sharply divided as to the type of control required, and the resulting public indifference and official lack of co-operation have made all legislation ineffective. Popular propaganda against venereal disease has not played a large part in either programme. Private associations and organizations have not done much to inform the public of the dangers involved, nor have they attempted to combat the social stigma attached to venereal disease which too often results in neglect of treatment by those infected or in attempts at home cures. Indeed, these organizations have played a negative part, their chief activity being directed to fighting " public immorality" by destroying the maisons tolérées and the carte system. Since 1938, all legislation on the subject has tended to increase the responsibility of the physician, and to make him the channel through which sanctions may be applied against the recalcitrant patient. This has generally been resented and opposed by physicians, and when their services have been conscribed results have not been good. Further, there has been a sharp split between the pre-war and the Vichy attitude on the one hand, and the post-war attitude on the other. Since most medical men favour the former and are not in sympathy with the new system of regulation, their co-operation is even more reluctant. This controversy over the control of prostitution, which continues unabated, must be at the heart of any assessment of post-war policy.

Those supporting the new legislation argue that the medical supervision and control of prostitutes in the licensed brothels and en carte was a failure since all case studies show that a percentage of infections were due to these groups. If it is maintained that this percentage was smaller than infections from any other source, the reply is that these prostitutes formed so small a part of the total number that they gave the client an illusion of security, since he tended to think that all prostitution was supervised by the police or the public health authorities. However, the new system is chiefly justified not on public health grounds but on those of morality. The dissolution of the " houses" is approved quite apart from any effect it might have on the incidence of venereal disease. The main force behind the new legislation was organized opinion which considered the licensing of prostitution to be morally indefensible. The reform organizations maintain that, far from solving the problem of prostitution, the old

T ABLE I

NUMBER* OF DECLARED NEW CASES OF VENEREAL DISEASE

\begin{tabular}{|c|c|c|c|c|c|c|c|c|c|}
\hline \multirow{2}{*}{ Disease } & \multirow{2}{*}{ Area } & \multicolumn{8}{|c|}{ Year } \\
\hline & & 1945 & 1946 & 1947 & 1948 & 1949 & 1950 & 1951 & 1952 \\
\hline \multirow[t]{2}{*}{ Gonorrhoea } & Metropolitan France & 34,787 & 29,906 & 25,811 & 24,257 & 21,324 & 17,888 & 14,665 & 15,098 \\
\hline & Departement of the Seine & 10,084 & 11,709 & 12,187 & 13,113 & $12,0 \leq 1$ & 10,887 & 8,877 & 9,256 \\
\hline \multirow{2}{*}{$\begin{array}{l}\text { Primary and } \\
\text { Secondary } \\
\text { Syphilis }\end{array}$} & Metropolitan France & 12,094 & 15,454 & 12,255 & 8,681 & 4,819 & 2,773 & 1,998 & 1,874 \\
\hline & Département of the Seine & 3,321 & 5,965 & 4,920 & 3,473 & 1,776 & 1,091 & 945 & 920 \\
\hline \multirow[t]{2}{*}{ Soft Chancre } & Metropolitan France & 1,495 & 1,060 & 421 & 327 & 262 & 178 & 175 & 138 \\
\hline & Departement of the Seine & 118 & 242 & 75 & 27 & 19 & 17 & 22 & 22 \\
\hline
\end{tabular}

*The above figures cannot be taken as representing all the new cases of venereal disease in the respective years. Most of the declarations originate from hospital and municipal clinics. Physicians, who are the chief agents for treatment, are notoriously lax in reporting patients. Statistics provided by Dr. Aujaleu, Direction de l'Hygiène Sociale, Ministère de la Santé Publique et de la Population, in a letter dated Statistics pro
June 6,1953 . 
scheme encouraged it by creating a demand which in turn was satisfied by the clandestines. The argument here seems to be based on the record of such areas as Paris and Marseille, where not only the brothels flourished but there were also more clandestines operating than in cities such as Lyon, Strasbourg, and Grenoble, where local bye-laws had already abolished the municipal "houses". But the comparison is not really valid, because both Marseille and Paris had special characteristics, not unrelated to the problem, which were not shared by other cities.

Much more serious was the charge that the licensing of prostitutes directly increased the ranks of the clandestines because once the woman contracted a venereal disease and was dismissed from employment or deprived of her carte she went underground in order to continue working. Gounelle and Girault (1947) estimated that licensed prostitutes accounted for 10-30 per cent. of the venereal disease infections, and that in Paris in 1942 there were 1,500 women in licensed houses, 5,000 holding cards, and 80,000 clandestines. Bertier (1945) estimated that there were approximately 200 clandestines in the Bordeaux area in 1937-39; 480 in 1940 ; 940 in $1941 ; 1,130$ in 1942 ; and 750 in 1943. Finally, and this contention appears unassailable, it is held that the controls had broken down under the tremendous increase in clandestines and amateur prostitution during the war (Cavaillon, 1946 ; Leroy-Boy, 1946).

Even if all these new prostitutes could have been included in the old scheme, the police would have been unable to cope with the amount of supervision required, and, therefore, it was argued that it was preferable to place this work entirely in the hands of the medical profession. Having done this, it was then necessary to replace the coercive element by something less penal in character : the epidemiological investigation. Unfortunately, it was later found necessary to supplement this by the list of prostitutes, and ironically the latter, although administered by the public health authorities, is in many respects more coercive than the old system.

Those opposed to the new legislation maintain that it is inefficient and that the former controls were better than the anarchy which followed their abolition. Many physicians complained that the houses were closed and the card system destroyed before any thought was given to alternative regulations, with the result that there was no decrease in prostitution but a lowering of the sanitary standards among prostitutes and a consequent increase in venereal disease among the population generally (Blum, 1947).*

By 1948 the government was forced to replace the old controls by a sort of clandestine tolérée status. Some medical critics base their entire case on observations of what occurred in their own communities and practices (or clinics) after April and September, 1946. Most of the former employées and prostitutes en carte worked in the streets or formed groups frequenting cafés, bars, and dance-halls. Many of the private licensed houses simply transformed themselves into night clubs and similar establishments, and carried on their prostitution business illegally without inspection or examination. Such activities are reported at St. Etienne (Duverne, 1947), Paris (Blum, 1947), and Marseille (Vigne and Bourret, 1947); these resulted in a tremendous increase in the number of arrests and trials on charges of soliciting and procuring (Table II).

TABLE II

NUMBER OF PERSONS TRIED AND CONVICTED ON CHARGES OF PROCURING AND SOLICITING

\begin{tabular}{c|c|c|c}
\hline \multirow{2}{*}{ Year } & \multicolumn{3}{|c}{ Charge } \\
\cline { 2 - 4 } & Procuring & \multicolumn{2}{|c}{ Soliciting } \\
\cline { 2 - 4 } & & Men & Women \\
\hline 1946 & 552 & 43 & 1,919 \\
1947 & 1,308 & 61 & 2,794 \\
1948 & 1,142 & 77 & 2,973 \\
1949 & 1,154 & 50 & 2,838 \\
1950 & 1,088 & 64 & 2,758 \\
1951 & 860 & 158 & 2,806 \\
$1952^{*}$ & 565 & 14 & 1,111 \\
\hline
\end{tabular}

* Cases tried in the courts of Paris are not included in the total for 1952 because they are not yet available. The 1951 totals for these courts (included above) were 318 (procurers), 139 (pimps), and 1,589 (women soliciting).

Statistics provided by Dr. Aujaleu, Direction de l'Hygiène Sociale, Ministère de la Santé Publique et de la Population, in a letter dated July 25, 1953.

They represented more trouble for the police in raids, etc. on such establishments, and for the medical profession in the sudden influx of cases of primary and secondary syphilis and gonorrhoea. To support this charge several physicians submitted reports to the Annales de Dermatologie et de Syphiligraphie comparing their experiences in 1945 and 1946. All found a sudden drop in the periodical visits of prostitutes, once these were no longer

* A resolution of the Société francaise de dermatologie passed unanimously on February 20, 1946, called for :

(i) The continued surveillance of prostitutes. logical investigation.

(iii) A campaign against clandestines.

(iii) A campaign against clandestines.

(v) A campaign against procuring.

It was demanded that any attempt to close the licensed houses and replace the carte system by some other control be deferred until the present alarming figures decline. 
compulsory. Table III records the work of the venereal disease service of Lyon before and after October 16, 1946 (the date of the final closure of the houses).

\section{TABLE III}

ACTIVITY OF THE VENEREAL DISEASE SERVICE OF LYON (EXAMINATIONS)

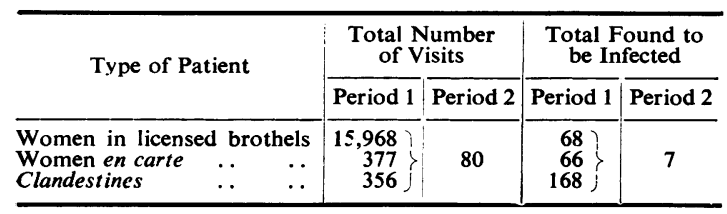

Period 1 ended on January 1, 1946 (before the control system was abolished) : Period 2 runs from January 2, 1946 to October 17, 1946. Lacassagne and others (1947).

In Marseille after October 1, 1946, the number of prostitutes who were periodically examined dropped to one-twentieth of the former figure (Vigne and Bourret, 1947). The Dispensaire de salubrité of the Hôpital St. Lazare in Paris tried to ensure that the prostitutes on their books continued under their supervision. Accordingly, their social workers contacted the women, asking them to visit the clinic to discuss their future. Of the 923 formerly employed in licensed brothels 519 attended-93 of them had already obtained employment and had labour permits, 154 intended to cease prostitution and were looking for work, 92 had sufficient money to live for several months and had not yet decided whether to return to prostitution or not, 21 had married, and eleven were about to leave for their homes overseas or in the provinces. Thus, 371 probably no longer required supervision. Of the remainder, 64 agreed to continue the visits on a voluntary basis (probably because they were already working on the streets, although this is not specifically stated), and 84 had health cards indicating supervision by private practitioners. Of the 404 women who did not appear for consultation, 65 were found to have given false addresses, and the others ignored repeated appeals. These were almost certainly clandestines. Information regarding the former prostitutes en carte is less detailed, but it was reported that whereas each of the private practitioners on the dispensary's panel had formerly examined from 350 to 400 weekly, they were receiving only 190 weekly by the end of 1946 (Blum, 1947).

The reports of all the critics suggest that there was an immediately noticeable deterioration in the health of the women. The percentage of their former patients who on arrest were found to be infected with venereal disease was very high indeed.
In Marseille alone, in February, 1947, 140 of the 275 prostitutes arrested were found to be in an infectious state. This was 50.9 per cent., whereas the average percentage of infectious cases arrested in 1945 had been only 6 per cent. (Vigne and Bourret, 1947.)

The Paris police figures of the number of prostitutes imprisoned are in inverse proportion to the total examined at the Hôpital St. Lazare. In January, 1946, the hospital was supervising 411 women, by May and June this had dropped to 52 and 35 ; in November it rose to 151 (no doubt because of the police activity of that summer). Between May 2 and November 30 the municipal police had arrested some 1,766 girls on charges of soliciting while infected with venereal disease and the police judiciaire held a further 319 on the same charge (Blum, 1947). On the other hand, the Paris police seem to have been entirely unable to deal with the prostitution centring in the night clubs, etc. Such raids as did take place revealed an appalling rate of venereal disease among the women. In the 6 months before April, 1946, there had been 13,388 arrests resulting from raids on illegal houses and similar centres of prostitution. In the 6 months after April, 1946, the arrests from raids totalled only 1,571 , but the percentage of infectious cases among the arrests rose from 20 to 37 per cent. (Blum, 1947).

Critics of the new legislation make two additional claims :

(i) that in replacing the licensed brothel system by what is, in effect, a clandestine tolérée scheme, the chance of the client's being infected has increased, since investigation of the different groups of prostitutes in the years before 1946 revealed considerably better health among the employées of "houses" than among any other prostitutes ;

(ii) that the declaratory system together with the epidemiological investigation is even less efficient than the former police supervision.

It will be remembered that compulsory notification of cases by number was introduced in 1942 . Therefore, it is not surprising that the number of cases reported increased immediately thereafter. But since a large part of the medical profession opposes the system and is lax in reporting patients no accurate analysis can be made of the general position. The proportions of the rise due to greater morbidity and to a higher percentage of declarations is not known. Table IV shows a 39 per cent. increase in declarations in the Département of the Seine between 1942 and 1944, 28 per cent. between 1944 and 1945, and 32 per cent. between 1945 and 1946, 
but the figures are of little value in determining the actual state of the disease in these years.

TABLE IV

NUMBER OF DECLARED NEW CASES OF VENEREAL DISEASE IN THE DÉPARTEMENT OF THE SEINE

\begin{tabular}{|c|c|c|c|c|}
\hline \multirow{2}{*}{ Year } & \multicolumn{3}{|c|}{ Disease } & \multirow{2}{*}{ Total } \\
\hline & Gonorrhoea & Syphilis & Others & \\
\hline $\begin{array}{l}1942 \\
1943 \\
1944 \\
1945 \\
1946\end{array}$ & $\begin{array}{r}6,432 \\
5,512 \\
7,290 \\
10.081 \\
11,709\end{array}$ & $\begin{array}{l}3,394 \\
3,774 \\
3,359 \\
3,471 \\
6,111\end{array}$ & $\begin{array}{r}\overline{1,004} \\
3 \\
122 \\
248\end{array}$ & $\begin{array}{r}9,826 \\
10.290 \\
10,652 \\
13,674 \\
18,068\end{array}$ \\
\hline
\end{tabular}

Spillmann and others (1946, 1947).

According to Spillmann and others (1947) :

The participation of the medical profession in the application of the law of December 31, 1942, remains insignificant. ...

In a similar report, Renard (1946) admitted that :

... these figures are manifestly very much smaller than the number of cases reasonably to be expected, particularly those of gonorrhoea.

Similarly Aujaleu and Péquignot (1947) considered that :

The declared cases of venereal diseases only constitute a small part of the actual cases. Many physicians, in spite of the obligation placed on them by the law, do not notify the cases which they observe; 1 per cent. of the notification of gonorrhoea cases and 5 per cent. of those of syphilis are made by private practitioners, all the others come from the services [i.e. the hospitals and the public clinics].

Even those physicians who favour the new system would probably admit that their efforts at epidemiological investigation show a high failure rate. They have not the time, training, or facilities for this work, and the information they pass on to the civil authorities is generally inadequate. The difficulty is that the inquiry depends on the goodwill of both patient and doctor, and in too many cases neither is disposed to help. Speed, which is essential in tracing the source of infection and subsequent contacts, is usually lacking. Even when aware of the source of infection, many patients are unwilling to reveal it, and therefore either state that they do not know, or give false or incomplete information. In addition, there seems to be a tendency to give certain "acceptable" replies: thus men will frequently name a prostitute as the agent (who is often subsequently proved to be free from infection), and women will name their husbands. The reports of Spillmarn and others $(1946,1947)$ for the Département of the Seine show an average rate of only
35 per cent. success in locating the alleged contact in declared cases treated by public clinics (Table V).

TABLE V

RECORD OF EPIDEMIOLOGICAL WORK IN THE DÉPARTEMENT OF THE SEINE

\begin{tabular}{|c|c|c|c|c|}
\hline \multirow{2}{*}{ Year } & \multirow{2}{*}{$\begin{array}{c}\text { Status of } \\
\text { Patient }\end{array}$} & \multicolumn{3}{|c|}{ Number of Contacts } \\
\hline & & Sought & Located & $\begin{array}{l}\text { Found to be } \\
\text { Infected }\end{array}$ \\
\hline 1944 & - (all) & 256 & 98 & 60 \\
\hline 1945 & $\begin{array}{l}\text { Civil } \\
\text { Military } \\
\text { Provincial }\end{array}$ & $\begin{array}{r}1,213 \\
7,113 \\
872\end{array}$ & $\begin{array}{r}463 \\
2,494 \\
297\end{array}$ & $\begin{array}{r}234 \\
1,019 \\
\end{array}$ \\
\hline 1946 & $\begin{array}{l}\text { Civil } \\
\text { Military } \\
\text { Provincial }\end{array}$ & $\begin{array}{r}1,264 \\
2,058 \\
954\end{array}$ & $\begin{array}{l}489 \\
806 \\
372\end{array}$ & $\begin{array}{l}237 \\
326 \\
157\end{array}$ \\
\hline
\end{tabular}

Spillmann (1945); Spillmann and others (1946, 1947).

Nor was the position much better in the investigations of recalcitrants who evaded treatment: 43.2 per cent. of the total of 356 patients resumed treatment in 1944, and 42 per cent. of the total of 1,823 in 1946 (Spillmann, 1945 ; Spillmann and others, 1947). This is a better record than that experienced by most venereal disease services; the difficulty was that, even when they were given adequate information, the hospital and other services had not sufficient social workers to conduct a thorough investigation quickly, and with attempts to cut government spending expansion became impossible. Thus the Law of February 2, 1946, forbade the creation of new posts, and that of December 23, 1946, called for a reduction of staff in all public establishments. According to Spillmann and others (1946) the proportion of social workers to the population of the area was the same in 1946 as in 1939-45 assistants for 6 million people. In the Département of the Rhôre in 1945 only 21 per cent. of the inquiries for persons infecting others with gonorrhoea and 31 per cent. of those for persons with syphilis were successful (Gaté, Robin, and Violet, 1946). Even in a small city the tracing of agents was not noticeably easier. The Dispensaire Fournier of Nancy, for example, had only 31.3 per cent. success in its 1945 investigations and 40 per cent. success in 1946 (Watrin, 1946, 1947).

Many critics of the new system even consider it responsible for part of the increased volume of venereal disease in France in the first years after the war. However, there is no real proof of this. Certainly the reports quoted above would seem to indicate that a greater proportion of infected prostitutes may now escape detection. But against this is the admission that the position of the vast majority (the clandestines) is virtually unchanged. 
It would appear that the sudden closure of the maisons tolérées in the second half of 1946 did give rise to a high incidence of disease, at least for several months. In February 1947 the dispensary at St. Etienne reported an increase of 60 per cent. in its cases of primary and secondary syphilis over the total of the previous year (Duverne, 1947), and for the civilian population of Paris and the Département of the Seine the morbidity for 1946 was estimated as 75 per cent. above that of 1945 .

Defenders of the new legislation, on the other hand, denied that the sudden increase of cases after October, 1946, was significant, by pointing out that the increase in incidence had been continuous since 1940 , that even sharper rises were registered in previous years, and that these reflected not increased morbidity but the more efficient declaration of cases. Thus the total of new cases in the Département of the Seine for 1946 was 183 per cent. above those for 1942. Yet the rise from 1941 to 1942 was 75 per cent. $(1,901$ to 3,394$)$ and that from 1942 to 1943 only 10 per cent. $(3,394$ to 3,774$)$ according to Périn (1943) and Spillmann and others (1947).

In denial of the contention that the period immediately following the closure of the houses and the withdrawal of the cartes was one of high venereal morbidity, Cavaillon (1948b) quotes the monthly statistics of reported new cases of syphilis in the Département of the Seine :

1946: $\begin{array}{llll}\text { September, } & 856 & \text { November } & 532 \\ \text { October } & 464 & \text { December } & 578 \\ 1947: \text { January } & 451 & \text { June } & 368 \\ \text { February } & 400 & \text { July } & 377 \\ \text { March } & 579 & \text { August } & 401 \\ \text { April } & 407 & \text { September } & 365 \\ \text { May } & 478 & \text { December } & 345\end{array}$

The importance of venereal disease as a cause of death is frequently hidden in reports of vital statistics. The number of deaths involved is, of course, slight compared with such diseases as cancer or tuberculosis, and there has been no special campaign to acquaint the general public with the extent of the morbidity and mortality involved (or indeed of such special results as infant mortality from congenital syphilis). Whenever public attantion has been directed to the venereal disease programme it has been focused on prostitution and the controversy over various morality-control systems. Table VI, showing the total deaths from venereal disease, reveals how little progress has been made. Considering the tremendous improvement in methods of treatment which has taken place since 1935, the reduction in the number of fatal cases between 1935 and 1951 is very slight. The fault, of course,
TABLE VI

TOTAL DEATHS FROM VENEREAL DISEASE IN FRANCE, BY YEAR AND SEX

\begin{tabular}{|c|c|c|c|c|}
\hline \multirow[t]{2}{*}{ Year } & \multicolumn{2}{|c|}{ Syphilis } & \multicolumn{2}{|c|}{$\begin{array}{l}\text { Locomotor Ataxia, } \\
\text { General Paralysis of } \\
\text { the Insane }\end{array}$} \\
\hline & Male & Female & Male & Female \\
\hline $\begin{array}{l}1935 \\
1936 \\
1940 \\
1941 \\
1942 \\
1943 \\
1944\end{array}$ & $\begin{array}{l}155 \\
177 \\
318 \\
391 \\
414 \\
232 \\
414\end{array}$ & $\begin{array}{l}111 \\
119 \\
214 \\
248 \\
295 \\
155 \\
336\end{array}$ & $\begin{array}{r}1,034 \\
995 \\
960 \\
1,232 \\
962 \\
762 \\
497\end{array}$ & $\begin{array}{l}783 \\
694 \\
581 \\
599 \\
579 \\
555 \\
321\end{array}$ \\
\hline $\begin{array}{l}1944 \\
1945 \\
1946 \\
1947 \\
1948 \\
1949 \\
1950 \\
1951\end{array}$ & $\begin{array}{r}1,123 \\
1,010 \\
959 \\
919 \\
990 \\
913 \\
1,177 \\
1,099\end{array}$ & $\begin{array}{l}764 \\
765 \\
662 \\
586 \\
565 \\
561 \\
764 \\
734\end{array}$ & & \\
\hline
\end{tabular}

The first part of the Table uses the international nomenclature agreed upon in 1929, the second the revised nomenclature agreed in 1938. Syphilis from 1944 (revised figure) therefore includes locomotor ataxia and general paralysis.

Figures for the years 1937-39 were destroyed during the war. Those for the years 1940-42 concern 87 departements, those for 1943 and 194486 departements. The figures for the years from 1949 on are provisional.

Instifut National de la Statistique et des Etudes Economiques (1952). Annuaire Statistique (vol. 58, for the year 1951), pp. 71-4, Ministere des Finances et des Affaires Economiques, Paris.

lies in the failure to make the anti-venereal disease programme a matter of public interest. Thus far it has remained the concern only of a very restricted number of demographers, sociologists, and physicians.

In addition, if success in the control of the disease is to be ensured, the emphasis of policy must be placed on treatment rather than prevention, where there exist such differences of opinion on control methods and the problem of public morality fogs the issue. More funds must be made available to private practitioners and clinics for free treatment, and the active co-operation of the medical profession must be obtained by making it quite clear that no physician will be required to betray the confidence of his patient.

\section{Summary}

The legislation designed to control prostitution and venereal disease in France is reviewed. The pre-war and Vichy government system of licensing brothels and individual prostitutes is described and the effect of the post-war abolition of this system on the public health is discussed. The responsibilities of medical practitioners and the police are described. The new programme has aroused acute controversy in France. The medical profession dislike compulsory notification of infectious cases 
and the legal duty of carrying out epidemiological investigations for which they have neither the time nor the facilities. Reliable statistics on prostitution and morbidity from venereal disease are difficult to obtain, but in so far as they are available they have been used to assess the claims of the supporters and the opponents of the new policy.

\section{REFERENCES}

Aujaleu, -, and Péquignot, H. (1947). Sem. Hôp. (Paris), 23, No. 18, p. 1218.

Bertier, J. C. de (1945). “ "La prostitution à Bordeaux de 1939 à 1944." Thesis, Bordeaux. [Abs. in Ann. Derm. Syph. (Paris), 1946, sér. 8, 6, 210].

Blum, P. (1947). Ann. Derm. Syph. (Paris), sér. 8, 7 ; Bull., No. 57, p. 34.

Bureau, Y. (1944). Collection du Droit Social, No. 22, “La médicine sociale : bilan et perspectives d'avenir", pp. 50-54

Cavaillon, A. (1945). Bull. Acad. Méd. (Paris), 129, 124.

- (1946). Ann. Derm. Syph. (Paris), sér. 8, 6, 162.

(1948a). Inform. soc. (May 1), 2, 505.

$-(1948$ b). Ibid., 2, 500.

Duverne, J. (1947). Ann. Derm. Syph. (Paris), sér. 8, 7 ; Bull., No. 57 , p. 83 .

Frappa, J.-J. Thesis, "Enquête sur la prostitution" (Quoted by Lahille, 1939).
Gaté, J., Robin, P., and Violet, P. (1946). J. Méd. Lyon, 27, 609.

Gounelle, H., and Girault, P. (1947). Presse méd., 55, 47.

Lacassagne, J., Rousset, J., and Cuilleret, P. (1947). Ann. Derm. Syph. (Paris), sér. 8, 7 ; Bull., No. 57, p. 135.

Lahille, A. (1939). " Démographiques, médico-sociales, et sociales ", in "Questions d'actualité ", p. 255. Paris.

Leroy-Boy, J. (1946). "International Congress on Family and Population", vol. 4, "Questions sociales", p. 47. Éditions Familiales, Uitgaven, Brussels.

Ministère de la Population et de la Famille (1948a). Textes de Droit Familial, vol. 6, "La lutte contre la prostitution", p. 2. (1948b). Ibid., p. 6.

Périn, L. (1941). Paris méd., 31, Nov. 30 (Nos. 47-48), p. 1. (1943). Ann. Derm. Syph. (Paris), 3-4, 75.

Peytel, A. (1944). Collection du Droit Sccial, No. 22, "La médicine sociale : bilan et perspectives d'avenir", p. 51.

(1945). Paris Méd., 35, July 30, (No. 21), p. 157

Renard, J. (1946). Bull. Inst. nat. Hyg. (Paris), $1,18$.

Spillmann, A. (1945). Ann. Derm. Syph. (Paris), sér. 8, 5, 96. Bidegaray, -, and Bourjaillat, -. (1946). Ibid., sér. 8, 6, 157.

,--1 (1947). Ibid., sér. 8, 7 ; Bull., No. 57, p. 106.

Touraine, A. (1937). Bull. Soc. Frans. Derm. Syph. (Paris), 44, 689 (séance, April 15).

- (1942). Proph. antivénér., 14, - (Cited by Bureau, 1944).

UNRRA (1945). Epidemiological Information Bulletin, 1, 403. “Epidemiological Notes ", signed K.S.

Vigne, P., and Bourret, M. (1947). Ann. Derm. Syph. (Paris), sér. 8, 7 ; Bull., No. 57, p. 109.

Watrin, J. (1946). Ibid.. sér. 8, 6, 161.

—(1947). Ibid., sér. 8, 7 ; Bull., No. 57, p. 102. 